\title{
UPAYA MENINGKATKAN PRESTASI BELAJAR SISWA PADA \\ PELAJARAN PKN MELALUI METODE MIND MIPPING \\ PADA SISWA KELAS III SD NEGERI 166492 \\ KOTA TEBING TINGGI
}

\author{
Manginar Simamora \\ Surel: manginarsimamora10@gmail.com
}

\begin{abstract}
ABSTRAK
Penelitian ini bertujuan untuk mendeskripsikan dan menganalisis proses pembelajaran pendidikan kewarganegaraan melalui metode Mind Mapping yang dapat meningkatkan prestasi belajar siswa Kelas III SD Negeri 166492 Kota Tebing Tinggi. Penelitian ini merupakan penelitian tindakan kelas (PTK) yang dilaksanakan secara kolaboratif antara guru dan peneliti dan subyek penelitiannya adalah siswa Kelas III. Adapun pengumpulan data dilakukan dengan observasi, wawancara, dokumentasi dan tes. Penelitian ini dilakukan dengan dua siklus yaitu siklus I dan siklus II. Hasil penelitian menunjukkan bahwa adanya peningkatan prestasi belajar siswa. Pada siklus I siswa memperoleh rata-rata nilai 65,48 . Lalu pada siklus II telah meningkat, rata-rata kelas menjadi 84,63 Nilai rata-rata dari pra siklus adalah 75,05. Berdasarkan hasil penelitian tersebut telah terjadi peningkatan pada setiap siklusnya.
\end{abstract}

Kata Kunci: Mind Mapping, Prestasi Belajar, PKN

\section{PENDAHULUAN}

Setiap saat pendidikan selalu menjadi fokus perhatian, bahkan tidak jarang menjadi sasaran ketidakpuasan karena pendidikan menyangkut kepentingan semua orang. Pendidikan tidak hanya menyangkut investasi dan kehidupan di masa yang akan datang, melainkan juga menyangkut kondisi dan suasana kehidupan saat ini. Itulah sebabnya pendidikan senantiasa memerlukan perbaikan dan peningkatan, sejalan dengan semakin tingginya kebutuhan dan tuntutan kehidupan masyarakat.

Kurikulum tingkat satuan pendidikan (KTSP) sebagai kurikulum yang disusun dan ditetapkan secara lokal dipandang memiliki tingkat efektivitas tinggi dan diharapkan dapat memberikan keuntungan, seperti kebijakan dan kewenangan sekolah membawa pengaruh langsung terhadap peserta didik, orang tua dan para pendidik, bertujuan untuk memanfaatkan sumber daya lokal secara efektif dalam melakukan pembinaan peserta didik, hasil belajar, tingkat pengulangan, tingkat putus sekolah, moral peserta didik, para pendidik dan iklim sekolah. Selain itu dibutukan adanya suatu perhatian bersama untuk mengambil keputusan dalam memberdayakan guru,

Guru SD Negeri 166492 Kota Tebing Tinggi 
manajemen sekolah dan perubahan perencanaan pengelolaan sekolah.

Dengan demikian upaya pencapaian tujuan pendidikan nasional maupun tujuan kelembagaan dipengaruhi oleh kemampuan guru dalam meningkatkan profesionalitas nya untuk menciptakan proses pembelajaran secara optimal dan mampu mengevaluasi secara obyektif. Evaluasi pembelajaran yang dilakukan oleh seorang pendidik tentunya harus mengacu pada kriteria ketuntasan minimal (KKM) yang terdapat dalam kurikulum. KKM merupakan tolak ukur pencapaian tujuan pembelajaran dari setiap mata pelajaran, standar kompetensi, kompetensi dasar dan indikator. Agar KKM yang ditetapkan menjadi tolak ukur yang absah tentunya harus memenuhi standar penilaian pendidikan sesuai dengan Peraturan Menteri Pendidikan Nasional Republik Indonesia nomor 20 Tahun 2007 yang isinya, "Bahwa dalam rangka mengendalikan mutu hasil pendidikan sesuai standar nasional pendidikan dikembangkan oleh Badan Standar Nasional Pendidikan, perlu menetapkan Standar Penilaian Pendidikan dengan peraturan menteri pendidikan nasional". Standarisasi penilaian yang disusun dan ditetapkan di sekolah oleh seluruh komponen pendidikan dalam rapat akhir tahun sebagai persiapan menghadapi tahun pelajaran baru yang lebih baik.

Mata pelajaran Pendidikan Kewarganegaraan merupakan salah satu mata pelajaran yang memfokuskan pada pembentukan karakter siswa yang memahami dan mampu melaksanakan hak-hak dan kewajibannya untuk menjadi warga Negara yang baik, cerdas, terampil dan berkarakter yang diamanatkan oleh Pancasila dan UUD 1945, serta memfokuskan pada pembentukan diri yang beragam dari segi agama, sosiokultural, usia dan suku bangsa. Pendidikan Kewarganegaraan oleh sebagian anak sering kali dianggap sebagai mata pelajaran yang membosankan, yang hanya mementingkan hafalan semata dan kurang menekankan pada aspek penalaran. Hal ini menyebabkan rendahnya minat untuk belajar PKn. Selain itu cara guru dalam penyampaian materi masih mengandalkan cara-cara lama yang kurang melibatkan keaktifan siswa dalam kegiatan pembelajaran.

Pembelajaran pendidikan kewarganegaraan di SD Negeri 166492 memerlukan model pemebelajaran yang mampu menciptakan suasana pembelajaran yang menarik serta dapat dilakukan adalah dengan memilih model pembelajaran yang dapat memberikan kesempatan seluas-luasnya kepada siswa untuk berkembang. Oleh karena itu disini peneliti mempunyai inisiatif untuk merubah metode dari metode ceramah ke dalam metode Mind Mapping.

Penggunaan metode Mind Mapping, diharapkan dapat merubah 
dan meningkatkan keberhasilan pelajaran Pendidikan

Kewarganegaraan Kelas III SD Negeri 166492 . Berdasarkan kondisi tersebut, maka peneliti mengadakan penelitian dengan judul :"Upaya meningkatkan prestasi belajar siswa pada pelajaran PKn melalui metode Mind Mapping pada siswa Kelas III SD Negeri 166492 Kota Tebing Tinggi tahun pelajaran 2017/2018".

Berdasarkan latar belakang tersebut diatas, maka dapat diambil rumusan masalah, sebagai berikut :

a. Bagaimana prestasi belajar siswa dalam pembelajaran PKn materi Memahami sistem pemerintahan desa dan pemerintah kecamatan sebelum diterapkannya metode Mind Mapping pada Kelas III SD Negeri 166492 Tebing Tinggi?

b. Bagaimana penerapan metode Mind Mapping dalam meningkatkan prestasi belajar siswa dalam pembelajaran PKn pada siswa Kelas III SD Negeri 166492 Tebing Tinggi?

c. Bagaimana perbandingan prestasi belajar siswa Kelas III pada mata pelajaran PKn materi kebebasan berorganisasi antara sebelum dan sesudah diterapkannya metode Mind Mapping ?

Adapun tujuan penelitian ini yaitu:

a. Untuk meningkatkan motivasi belajar peserta didik pada pembelajaran PKn tentang bentuk pengambilan keputusan dalam bermusyawarah.

b. Mengkaji bagaimana cara membelajarkan peserta didik mengenai konsep dan nilai konsep PKn tersebut agar menjadi manusia yang cerdas, terampil, bertanggung jawab sebagai warga negara, serta berpartisipasi aktif dalam bermasyarakat, berbangsa dan bernegara.

c. Melalui penerapan metode mind mapping dapat meningkatkan prestasi belajar peserta didik pada pembelajaran Pendidikan Kewarganegaraan tentang materi Memahami sistem pemerintahan desa dan pemerintah kecamatan

Sedangkan manfaat dalam penelitian ini yaitu:

1. Manfaat bagi peserta didik

a. Perbaikan akan membawa dampak positif bagi peserta didik, karena mereka akan mendapat kesempatan untuk lebih berperan aktif dalam proses pembelajaran dan menumbuhkan rasa percaya dirinya.

b. Perbaikan dengan menerapkan metode mind mapping akan membawa peserta didik ke situasi belajar yang bervariatif sesuai karakteristik materi yang dikolaborasikan dengan metode-metode pembelajaran yang diterapkan oleh guru. 
c. Perbaikan akan meningkatkan prestasi belajar peserta didik terhadap konsep dan nilai konsep PKn dalam pembelajaran secara maksimal.

2. Manfaat Bagi Guru

a. Perbaikan dimanfaatkan guru untuk memperbaiki proses pembelajaran yang dikelolanya sehingga dapat mencapai hasil pembelajaran secara optimal.

b. Perbaikan yang dilakukan oleh guru akan mendapat kesempatan untuk mengembangakan ilmu pengetahuan dan keterampilan profesional yang dimlikinya.

c. Perbaikan akan memotivasi guru untuk mencoba mengembangkan inovasi yang positif dalam membelajarkan peserta didiknya.

d. Perbaikan akan membuat guru selalu melakukan analisis terhadap kinerjanya, sehingga menemukan kekuatan dan kelemahan yang dimiliki, kemudian berusaha untuk mengatasi dengan alternatif pemecahan masalah yang akan menjadikan kekuatan rasa percaya terhadap kemampuan pada diri sendiri.
3. Manfaat Bagi Sekolah

Pendidikan di sekolah akan meningkat secara kualitas maupun kuantitas seiring dengan kemampuan profesional para pendidiknya. Selain itu, penanggulangan berbagai masalah belajar, perbaikan terhadap konsep yang keliru, serta kesulitan mengajar yang dialami akan segera teratasi.

\section{METODE PENELITIAN}

Jenis Penelitian sesuai dengan masalah yang diteliti, maka jenis penelitian yang dilakukan oleh peneliti berupa Penelitian Tindakan Kelas (PTK), yaitu suatu kegiatan penelitian yang dilakukan di kelas dalam arti luas. Suharsimi Harikunto (2006:2) memandang Penelitian Tindakan Kelas sebagai bentuk penelitian yang bertujuan untuk meningkatkan hasil belajar siswa, sehingga penelitian harus menyangkut upaya guru dalam bentuk proses pembelajaran.

PTK, selain bertujuan untuk meningkatkan hasil belajar, juga untuk meningkatkan kinerja guru dan dosen dalam proses pembelajaran. Dengan kata lain, PTK bukan hanya bertujuan untuk mengungkapkan penyebab dari berbagai permasalahan yang dihadapi, tetapi yang lebih penting adalah memberikan pemecahan berupa tindakan untuk mengatasi masalah.

Dengan demikian dapat disimpulkan bahwa PTK adalah suatu penelitian yang dilakukan untuk mengatasi masalah-masalah yang ada 
dalam proses pembelajaran dan upaya meningkatkan proses serta hasil belajar.

Penelitian ini dilakukan di

SD Negeri 166492 Kota Tebing Tinggi yang terletak di jalan Ir. $\mathrm{H}$. Djuanda Kecamatan Tanjung Marulak, Kota Tebing Tinggi. Penelitian ini dilakukan pada bulan Agustus-Oktober 2017 (semester I tahun pelajaran 2017/2018) dengan standar kompetensi, Menampilkan perilaku kemerdekaan mengemukakan pendapat, sedangkan Kompetensi Dasar (KD):

- Mengenal lembaga-lembaga dalam susunan pemerintahan desa dan pemerintah kecamatan.

- Menggambarkan struktur organisasi desa dan pemerintah kecamatan.

Subjek penelitian adalah siswa Kelas III yang berjumlah 27 orang, terdiri dari 13 orang laki-laki dan 14 orang perempuan di SD Negeri 166492 Kota Tebing Tinggi.

Pada prinsipnya diterapkannya penelitan tindakan kelas atau classroom action research dimaksudkan untuk mengatasi suatu permasalahan yang terdapat didalam kelas.

Sebagai salah satu penelitian yang dimaksudkan untuk memecahkan permasalahan di dalam kelas, menyebabkan terdapatnya beberapa model atau desai yang dapat diterapkan. Desain tersebut di antaranya : 1) Model Kurt Lewin 2) Model Kemmis \& MCTanggart 3) Model Dave Ebbut 4) Model John Elliot 5) Model Hopkins, dan masih ada beberapa model lain, yang prinsipnya merupakan pengembangan dari model yang ada.

Penelitian ini menggunakan metode penelitian tindakan kelas dengan menggunakan desain penelitian dari model kemmis dan Mc Taggart Desain penelitian tindakan kelas ini terdiri dari empat tahap yaitu : perencanaan (planning), tindakan (action), pengamatan (observing) dan refleksi (reflecting). Keempat tahapan tersebut dilakukan dalam siklus berulang.

Pelaksanaan PTK minimal dilakukan dalam dua kali siklus. Adapun pelaksanaan PTK ini dilakukan dalam dua kali siklus. Dalam setiap siklus dilakukan satu tindakan diwujudkan dalam kegiatan pembelajaran selama satu kali pertemuan yang lamanya $2 \times 35$ menit. Pelaksanaan PTK dimulai dengan siklus pertama.

Apabila dalam siklus pertama sudah menunjukkan perbaikan atau keberhasilan dan tidak ada hambatan dari kegiatan yang dilakukan maka peneliti menetukan rancangan siklus kedua. Kegiatan pada siklus kedua dapat berupa kegiatan yang sma pada siklus pertama, tetapi pada umumnya kegiatan pada siklus kedua mempunyai tambahan perbaikan dari tindakan terdahulu. Jika peneliti merasa belum puas dengan 
keberhasilan pada siklus pertama dan kedua maka boleh melanjutkan ke siklus berikutnya dan seterusnya sampai guru dan peneliti merasa puasdengan penelitian tindakan kelas yang dilakukan.

\section{HASIL DAN PEMBAHASAN}

Siklus I ini merupakan perbaikan dari pratindakan dan. Siklus I dilakukan untuk menutupi kekurangan-kekurangan yang terdapat pada siklus I. Adapun tahapantahapan pada siklus I ini sama dengan tahapan pada siklus I hanya saja ditekankan dengan yang dilakuka pada siklus I adalah:

\section{a. Perencanaan}

Kegiatan yang dilakukan pada tahap perencanaan ini adalah menyusung rancangan kegiatan pembelajaran (RPP) yang akan dilaksananakan sebagaimana pada siklus I

\section{b. Pelaksanaan Tindakan}

Pelaksanaan tindakan yang dilakukan pada tahap ini adalah melaksanakan rencana pelaksanaan pembelajaran yang telah dibuat pada siklus I, yaitu mengenal lembagalembaga dalam susunan pemerintahan desa dan pemerintah kecamatan melalui metode Mind Mapping pada mata pelajaran PKn Kelas III SD Negeri 166492 Kota Tebing Tinggi.

\section{c. Observasi}

Peneliti mengamati kegiatan pembelajaran pada siklus I untuk mengetahi apakah sudah ada kemajuan pada proses pembelajaran dari pra tindakan ke siklus I.

d. Refleksi

Seluruh data dan informasi yang telah diperoleh kemudian sebagai landasan untuk menentukan apakah tujuan yang diharapkan sudah tercapai atau belum.

Analisis data yang dilakukan dalam penelitian ini adalah menggunakan analisi data deskriptif kualitif. Analisis data dalam penelitian kualitatif, dilakukan pada saat pengumpulan data berlangsung dan selesai pengumpulan data dalam periode tertentu.

Miles dan Huberman mengemukakan bahwa aktiitas dalam analisis data kualitatif dilakukan secara interaktif dan berlangsung secara terus menerus sampai tuntas, sehingga datanya sudah jenuh. Aktivitas dalam analisis data, yaitu data reduction, data display dan conclusion drawing/verification. Dari tabel di atas dapat kita lihat bahwa pada pertemuan I aktivitas siswa masih rendah. Untuk diketahui pada pertemuan I ini peneliti belum lagi menerapkan model pembelajaran Jigsaw, tetapi hanya berbentuk ceramah bervariasi disertai dengan penugasan. Di akhir pembelajaran baru peneliti membentuk kelompok 
untuk persiapan pembelajaran jigsaw pada pertemuan berikutnya. Pada pertemuan 2 peneliti. Berdasarkan kumpulan data yang diperoleh dari kolaborasi dengan teman sejawat serta catatan lapangan yang ada pada peneliti, ternyata sebagian besar siswa belum mampu menyelesaikan tugas dengan optimal, baik pada tahap kooperatif asal (tahap I), tahap ahli (tahap II), maupun tahap ke III. Tingkat keaktifan siswa sangat rendah dalam pembelajaran. Hal ini menunjukkan bahwa tujuan yang hendak dicapai sehubungan dengan pelaksanaan tindakan ini belum tercapai secara optimal.

Menurut pengamatan peneliti kegagalan siswa tampak dengan jelas dalam memanfaatkan waktu. Siswa belum mampu memanfaatkan waktu sesuai dengan yang dialokasikan untuk setiap tahapan.

Agar siswa dapat menyelesaikan tugas-tugas yang diberikan tersebut, maka perlu diberikan perpanjangan waktu. Akibat dari perpanjangan waktu ini adalah sedikitnya waktu yang tersedia untuk kegiatan presentasi hasil kerja kelompok.

Dari data kuesioner di atas, peneliti melihat bahwa pada umumnya siswa tahu tentang topik atau kompetensi dasar yang akan dipelajari. Ini terjadi karena setiap akan memasuki pelajaran, peneliti selalu menginformasikan Kompetensi Dasar (KD) atau Indikator apa yang akan dicapai. Selanjutnya data yang menunjukkan memperoleh hasil yang baik adalah mengenai model pembelajaran yang diterapkan. Menurut pengakuan siswa, model pembelajaran metode mind mapping disenangi oleh siswa. Sehingga membawa dampak positif terhadap yang lain, seperti dapat melatih siswa untuk bertanggungjawab. Kemudian dampak lain yang sangat berpengaruh dengan disenanginya model pembelajaran yang diberikan adalah siswa menjadi termotivasi untuk bertanya, terutama saat berdiskusi. Dengan termotivasinya siswa saat berdiskusi, akhirnya aktivitas belajar siswa menjadi meningkat, sehingga dapat mendorong siswa untuk belajar lebih baik.

Data yang menunjukkan memperoleh hasil yang rendah adalah dalam hal menyampaikan informasi pelajaran kepada teman, maupun menerima informasi pelajaran dari teman. Hal ini peneliti sadari bahwa bagi siswa SD kelas III, memang masih sulit bagi mereka untuk menerangkan atau menyampaikan informasi pelajaran maupun menerima keterangan atau informasi pelajaran dari teman. Hal ini terjadi karena tingkat pengetahuan yang dimiliki oleh siswa masih rendah. Dengan melihat data kuesioner siswa yang telah dilaksanakan, peneliti berencana untuk dapat melaksanakan model pembelajaran metode mind mapping dalam proses pembelajaran selanjutnya sesuai dengan materi yang cocok. 


\section{SIMPULAN}

Berdasarkan hasil penelitian dan pembahasan tentang upaya meningkatkan prestasi belajar Pendidikan Kewarganegaraan melalui metode Mind Mapping pada siswa Kelas III SD Negeri 166492 Kota Tebing Tinggi diperoleh hasil sebagai berikut :

1. Tingkat prestasi belajar PKn siswa di kelas III materi. pemahaman sistem pemerintahan desa dan pemerintah kecamatan sebelum diterapkannya metode Mind Mapping masih sangat rendah belum mencapai kriteria ketuntasan minimal yang ditentukan untuk mata pelajaran PKN yaitu 68. Hal ini dapat dilihat dari perolehan hasil evaluasi yang dilakukan sebelum pra tindakan yang hanya memperoleh nilai rata-rata kelas 60,00 dengan presentase keberhasilan $22,22 \%$ belum mencapai indikator pada penelitian ini. Nilai terendah adalah 50 kategori kurang sedangkan nilai tertinggi adalah 75 kategori baik.

2. Rendahnya prestasi belajar PKn materi pemahaman sistem pemerintahan desa dan pemerintah kecamatan dipengaruhi oleh beberapa faktor diantaranya proses pembelajaran yang kurang menyenangkan. Kurangnya kemampuan guru dalam menggunakan media dan metode pembelajaran, serta kurangnya motivasi siswa dalam mengikuti proses pembelajaran

3. Penerapan metode Mind Mapping dalam pembelajaran PKn materi kebebasan berorganisasi pada siswa Kelas III SD Negeri 166492 berjalan dengan baik dan lancar. Penelitian tindakan kelas ini dilaksanakan dalam dua siklus. Siklus I dilaksanakan pada tanggal 24 Agustus 2017, 15 September 2017. Pertemuan kedua siklus I dilaksnakan pada 22 September 2017, 29 September 2017. dengan subyek sebanyak 27siswa. Pnerapan metode Mind Mapping ini dapat meningkatkan prestasi belajar siswa. Hal ini ditandai dengan adanya peningkatan prestasi pada tiap siklusnya.

4. Penerapan metode Mind Mapping mengalami peningkatan pada siklus II Hasil peningkatan prestasi belajar siswa dalam pembelajaran PKn materi pemahaman sistem pemerintahan desa dan pemerintah kecamatan dengan metode Mind Mapping sudah mencapai inndikator. Hal ini dilihat dari nilai rata-rata prestasi belajar PKn yang mengalami peningkatan dari mulai pra tindakan ke siklus I, dan siklus I ke Siklus II.

\section{DAFTAR RUJUKAN}

Amin, Z. I. 2006. Materi Pokok Pendidikan Kewarganegaraan. Jakarta: Universitas Terbuka. 
Baharuddin dan Esa Nur Wahyuni. 2007. Teori Belajar dan Pembelajaran. Yogyakarta: RUZZ Media.

Burhan Bungin. 2007. Penelitian Kualitatif: Komunikasi, Ekonomi, Kebijakan Publik dan Ilmu sosial Lainnya. Jakarta: Kencana.

Daryanto. 2005. Evaluasi Pendidikan. Jakarta: Rineka Cipta.

Departemen Pendidikan \& Kebudayaan RI, Kamus Besar Bahasa Indonesia. Jakarta: Balai Pustaka.

Depdiknas. 2007. Pedoman Pengembangan Silabus dan Model Pembelajaran. Buku IV. Jakarta: Dikmenum Depdiknas.

Djunaidi Ghony. 2008. Penelitian Tindakan Kelas. Malang: UINMalang Press.

http://ahmadsudrajat.wordpress.com/ 2013/09/09/mind-map-petapikiran/rabu 22 januari 2014. Pukul 14.00

Mulyasa. 2008. Implementasi Kurikulum Tingkat Satuan Pendidikan Kemandirian Guru dan Kepala Sekolah. Bandung: PT. Remaja Rosdakarya.

Sugiono. 2008. Metode Penelitian Pendidikan Kuantitatif,
Kualitatif Dan $R \& D$. Bandung: Alfabeta. 